\title{
BENEATH THE SURFACE
}





\section{BENEATH THE SURFACE}

Understanding Nature in the Mullica Valley Estuary

Kenneth W. Able

\section{Fi] RUTGERS}

New Brunswick, Camden, and Newark, New Jersey, and London 
Library of Congress Cataloging-in-Publication Data

Names: Able, Kenneth W., 1945- author.

Title: Beneath the surface : understanding nature in the Mullica Valley

Estuary / Kenneth W. Able.

Description: New Brunswick, New Jersey : Rutgers University Press, [2020] I

Includes bibliographical references and index.

Identifiers: LCCN 2019044065 | ISBN 9780813590202 (hardback) I ISBN

9780813590196 (paperback) I ISBN 9780813590219 (epub) I ISBN

9780813590226 (mobi) I ISBN 9780813590233 (pdf)

Subjects: LCSH: Estuarine ecology--New Jersey--Mullica River Watershed. I Valley ecology--New Jersey--Mullica River Watershed. I Natural history--New Jersey--Mullica River Watershed. I Mullica River Estuary (N.J.)--Environmental conditions I Mullica River Watershed

(N.J.)--Environmental conditions.

Classification: LCC QH105.N5 A25 2020 I DDC 577.7/86--dc23

LC record available at https://lccn.loc.gov/2019044065

A British Cataloging-in-Publication record for this book is available from the British Library.

Copyright (C) 2020 by Kenneth W. Able

All rights reserved

No part of this book may be reproduced or utilized in any form or by any means, electronic or mechanical, or by any information storage and retrieval system, without written permission from the publisher. Please contact Rutgers University Press, 106 Somerset Street, New Brunswick, NJ 08901. The only exception to this prohibition is "fair use" as defined by U.S. copyright law.

The paper used in this publication meets the requirements of the American National Standard for Information Sciences-Permanence of Paper for Printed Library Materials, ANSI Z39.48-1992.

www.rutgersuniversitypress.org

Manufactured in the United States of America 
To Judy Grassle and the late Fred Grassle, my long esteemed colleagues who I also count as dear friends. They have been a constant source of inspiration. 
